\title{
Historicismo: notas sobre um paradigma
}

\author{
Historicism: notes on a paradigm
}

José D’Assunção Barros ${ }^{1}$

RESUMO

Este artigo tem por objetivo desenvolver algumas considerações sobre o Historicismo e sua possibilidade de ser examinado como um dos paradigmas que concorrem para o estabelecimento de uma história científica no século XIX. O primeiro ponto tratado é relativo às origens do paradigma historicista na transição do século XVIII para o século XIX. Na sequência, aproximamo-nos da apropriação conservadora do paradigma historicista no novo contexto no qual a burguesia européia está assentada no Poder, combinando-se com a consolidação dos modernos estados-nações. A especificação das características deste paradigma constituem o principal ponto de análise.

Palavras-Chave: Historicismo. Historiografia. Historiografia Científica

\section{ABSTRACT}

This article aims to develop some considerations about the Historicism and the possibility of treat this as one of the paradigms that contribute to establish the scientific history in XIX century. The fist point treated is relative to the origins of the historicist paradigm in the transition from the XVIII century to de nineteenth century. In the sequence, we approach to the conservative appropriation of the historicist paradigm in the new context were the European bourgeois is assented in the Power, combined with the consolidation of the modern states-nations. The characteristics of this paradigm are the principal point of analysis.

Keywords: Historicism. Historiography. Scientific Historiography.

\footnotetext{
${ }^{1}$ Historiador e Doutor em História pela Universidade Federal Fluminense (Brasil).
} 
Não há grandes discordâncias entre os historiadores a respeito do momento em que, na história da historiografia ocidental, começa a surgir uma nova historiografia já auto-identificada como científica. De fato, esta nova historiografia que começa a despontar na curva do século XVIII para o XIX constituirá uma das grandes novidades da segunda modernidade, sendo a mesma contextualizada pela generalização da revolução industrial na Europa e no mundo político-social que emerge dos desdobramentos da Revolução Francesa e da Restauração. Contudo, se a nova historiografia científica se apresenta como uma destacada novidade em relação aos antigos gêneros historiográficos, a verdade é que também há uma dimensão conservadora entrelaçada nos primórdios desta nova historiografia científica, seja em uma ou outra de suas novas tendências paradigmáticas. A nova historiografia científica, aliás, lidará com este paradoxo: ao mesmo tempo em que imprimirá avanços significativos para a teoria e metodologia da história, boa parte dos novos historiadores não deixarão de atender a interesses vinculados aos poderes dominantes, particularmente sob o contexto de consolidação dos estadosnações e da burguesia europeia.

Enquanto o positivismo francês do século XIX pode ser discutido em geral como uma reconfiguração conservadora da herança iluminista, já o historicismo alemão, com seus desdobramentos em outros países europeus e nas Américas, deverá ser entendido em sua relação direta com o contexto de afirmação dos Estados-Nacionais. Assim, o historicismo ${ }^{2}$ também se presta nos seus primórdios, e no decurso de boa parte do século XIX, a um contexto igualmente conservador. Mas os interesses que representa mais diretamente não serão os da burguesia industrial enquanto classe social dominante, e sim os interesses dos grandes estados, da burocracia estatal que financia seus projetos historiográficos. Claro está que estes interesses são articulados em algum nível: o dos estados e o das elites que controlam a sociedade industrial ${ }^{3}$. Mas no plano mais direto, apresentam especificidades a considerar.

De todo modo, as duas grandes questões que se colocam para os historicistas alemães são a vontade de realizar a unificação alemã - uma vez que todo o vasto território de fala germânica estava então partilhado em inúmeras realidades políticas menores - e também o projeto de encaminhar a modernização sem maiores riscos revolucionários. Para além disto, particularmente com a Escola Histórica Alemã, os historicistas de primeira hora se apresentaram muito habitualmente sustentáculos das estruturas monárquicas - sendo particularmente forte a monarquia prussiana como financiadora do projeto nacional historicista sob sua jurisdição - e ainda havia uma boa parte de historicistas que buscavam justificar no passado as permanências e instituições feudais ainda persistentes no seu presente. De modo geral, no contexto da Restauração e em virtude das viscerais oposições entre alemães e franceses, os historiadores da

\footnotetext{
${ }^{2}$ Para um estudo dos sentidos possíveis de "Historicismo" (IGGERS, 1995, p.129-152; SCHOLTZ, 1974; OEXLE, 1986, p.119-155). ${ }^{3}$ A defesa dos interesses parlamentaristas ingleses combinada à apologia da industrialização, no quadro de uma historiografia historicista inglesa que representa o ponto de vista progressista-reformista dos whigs, pode ser bem representada por Thomas Babbington Macaulay (1800-1859). / Sobre a influência do historicismo alemão na Inglaterra oitocentista (DOCKHORN, 1950).
} 
Escola Histórica Alemã eram críticos da Revolução Francesa, e ao lado disto não desprezavam as épocas anteriores - inclusive a Idade Média - como haviam feito os iluministas do século XVIII. Qualquer época, para um historicista alemão, tinha a sua própria importância e deveria ser examinada consoante critérios a ela adequados, bem como de acordo com seus próprios valores. O mesmo raciocínio valia para as diversas espacialidades, e cada nação deveria ser compreendida em sua singularidade. O projeto inicial do Historicismo Alemão, conforme se pode ver, é por um lado tão conservador quanto o do positivismo francês, mas já apresenta um elemento novo, que é o de elaborar uma história especificamente nacional, portanto não universalista.

Para além disto, é oportuno lembrar que, do ponto de vista do estado prussiano, havia a tendência já herdada da época dos déspotas esclarecidos de fazer reformas de alcance limitado com o objetivo de se prevenir contra revoluções. Enquanto os monarcas absolutistas franceses haviam se conservado inflexíveis diante das pressões populares e por isso tiveram de enfrentar o acirramento e radicalismo da Revolução Francesa, os déspotas esclarecidos responsáveis pelas regiões que se relacionavam ao Império Austro-Húngaro - como Frederico II da Prússia e Dom José II da Áustria -aprenderam a acompanhar o movimento de sua época de modo a se conservar no poder. Alguns destes monarcas, à sua época, haviam se tornado "iluministas" moderados, benfeitores das artes e das ciências. No século XVIII, haviam oferecido um discurso de modernidade e uma prática de pequenas reformas; agora, ofereciam ao povo a história.

No fundo, tanto o Positivismo como o Historicismo foram, à partida, frutos de uma mesma necessidade de época, representada pelo paradoxo de encaminhar uma modernização política que viabilizasse aquele desenvolvimento industrial que atenderia às exigências da burguesia triunfante, e ao mesmo tempo conservar alguns privilégios sociais da nobreza (FONTANA, 2004, p. 222). Contudo, a esta necessidade em comum de realizar o consenso entre nobreza e burguesia, o Positivismo e o Historicismo ofereceram respostas diferenciadas: o positivismo francês oferecia o consenso com base na idéia de universalismo; o historicismo alemão buscava proporcionar o consenso social ancorado na idéia de nacionalismo. Para tanto, era necessário realizar uma nova forma de história, cujos dois principais pilares foram a recuperação de uma documentação alemã que remontava aos tempos medievais, e o desenvolvimento de um novo método de crítica destas fontes com inspiração filológica.

As motivações políticas das elites francesas e germânicas não diferiam muito, conforme se pode ver, no que se refere à necessidade de estabelecer consenso e de desmobilizar posturas revolucionárias; contudo, suas respostas a esta demanda demarcaram caminhos muito distintos, e o particularismo histórico proposto pelo historicismo alemão logo se oporá menos ou mais radicalmente ao universalismo positivista. De igual maneira, ao "homem universal" que um dia fora objeto de estudo dos iluministas, e que agora era reivindicado como conceito central pelos positivistas do século XIX, o Historicismo opunha o "indivíduo concreto", particular, histórico e sujeito à finitude. Ao menos em uma das pontas da operação historiográfica - a que se referia às 
fontes históricas e às sociedades examinadas (isto é, ao objeto historiográfico) - o Historicismo era já de certo modo relativista. Entenda-se bem, quando mencionamos esta faceta relativista do Historicismo estamos nos referindo ao seu modo de trabalhar com os seus objetos historiográficos, de reconhecer os particularismos das sociedades examinadas, de perceber que as fontes constituem também o discurso de uma época e de um lugar. Nesta forma relativizadora de trabalhar com as fontes históricas e de entender as sociedades a serem examinadas - ou nesta "ponta relativista", por assim dizer - conformava-se o seu avanço, a sua novidade com relação aos esquemas universalistas que o Positivismo herdara do Iluminismo, mas já despojados de seu caráter revolucionário.

É ainda preciso lembrar que o Historicismo teve precursores entre alguns dos filósofos e historiadores românticos do final do século XVIII, como o erudito italiano Giambattista Vico (1668-1774) ou o filósofo alemão Johan Gottfried Von Herder (1744-1803), que consideravam a necessidade de escrever uma história particularizante, capaz de apreender a especificidade de cada povo. De igual maneira, o Historicismo dificilmente poderia ter se formado, notadamente em sua base metodológica, sem a contribuição de alguns teólogos e filólogos alemães que já se debruçavam sob os problemas relacionados à interpretação de textos, e à inevitável articulação destes textos a contextos históricos específicos e a pontos de vista autorais. Pelo menos em um desses filólogos já podemos encontrar surpreendentes antecipações do perspectivismo historicista: Johann Martin Chladenius (1710-1759).

Este filólogo irá procurar refletir sistematicamente sobre a maneira de elaborar, de um lado, uma "história das gerações mais recentes" ancorada nos depoimentos orais (as "histórias presentes e futuras"), e, de outro lado, as "velhas histórias", que se estendem para os períodos mais recuados com relação aos quais é preciso investigar outros tipos de documentação. Na verdade, o que mais interessa a Chladenius refere-se mesmo aos períodos recentes, e ele valoriza mais aquilo que hoje se chamaria, mal aproximando uma época historiográfica da outra, de "história do tempo presente". A "história velha" é aquela que, a contragosto, escapa da vivacidade e maior veridicidade das "histórias das gerações recentes", uma vez que já não pode neste caso contar com depoimentos de pessoas vivas ${ }^{4}$.

Curiosamente, apesar das importantes contribuições que iria oferecer para uma nova história científica prestes a surgir em breve, Chladenius começara a trabalhar com esse viés

\footnotetext{
${ }^{4}$ Neste aspecto, os interesses de Chladenius coincidem com os que eram priorizados pelos historiadores antigos, notadamente os gregos. Podemos compará-lo com Tucídides. A Archaeologia, no início do relato de Tucídides sobre a Guerra do Peloponeso, é na verdade apenas uma pequena parte da obra, tal como indica Juliana Bastos Marques (2008, p. 53). O historiador grego pretendia dar mais atenção à história que se aproximava de sua época, de seu próprio presente, ou mesmo que coincidia com ele. Chladenius parece revelar, já no século XVIII, uma preferência análoga. Para ele, como observa Koselleck (2006, p. 168), "a velha história se inicia quando não há mais testemunhas oculares sobreviventes e nem se pode mais interrogar testemunhas auditivas vinculadas aos acontecimentos". Além disto, "as histórias do passado, situadas fora da lembrança coletiva, constituíam mero complemento da experiência histórica do presente" (p.172). Este jogo de prioridades estava por mudar, e a passagem do século XVIII para o XIX assistiria ao florescimento dos interesses em estudar os períodos mais recuados da história.
} 
bastante tradicional, que procurava valorizar os depoimentos oculares como mais importantes e confiáveis do que a documentação escrita, estabelecendo deste modo uma distinção respectiva entre as "histórias futuras" e as "velhas histórias". Heródoto (c.485-420 a.C.), na Grécia Antiga, já havia firmado esta valorização hierárquica dos depoimentos produzidos pelas testemunhas oculares, que para ele seriam preferíveis àqueles que se ancoravam no "ouvi dizer", e situando somente depois, no limite inferior da escala, a documentação e outros tipos de fontes que permitissem captar as informações para as quais já não havia nem testemunhos oculares e nem testemunhos de segunda mão. Mas a questão é que o nosso filólogo setecentista começa por reconhecer que os depoimentos prestados por testemunhos (oculares ou auditivos) são sempre relacionados a "pontos de vista". Depois, esta é a questão, Chladenius acaba por estender este reconhecimento de "relatividade dos pontos de vista" ao próprio historiador, dando a perceber que é a partir de um ponto de vista que este seleciona os próprios testemunhos e documentos que recolheu, para iniciar em seguida um trabalho de interpretação que também será interferido por este mesmo ponto de vista. Enfim, temos aqui, com uma clareza cartesiana, a consciência de que o historiador examina "pontos de vista" a partir do seu próprio "ponto de vista"6. Disso, naturalmente, também decorre que não existirá uma só história, ou que pelo menos não existirá uma única representação da história, e sim "diversas representações”, de acordo com os vários "pontos de vista"7.

Os cuidados em direcionar as técnicas da interpretação que já eram oferecidas pela hermenêutica para a análise dos depoimentos e dos documentos, e o reconhecimento pioneiro acerca da multiplicidade de "pontos de vista" que os atravessam, já revelam em Chladenius alguns dos elementos que logo seriam incorporados por uma prática historicista que irá triunfar no estabelecimento de uma historiografia científica, e, em alguns aspectos, pode-se dizer que Chladenius até mesmo ultrapassa o horizonte de relativismo histórico que foi possível ser alcançado pelos primeiros historiadores da Escola Histórica Alemã. Assim, o filólogo alemão antecipa até mesmo uma posição relativista mais avançada - aquela que não se contenta apenas em constatar a multiplicidade de pontos de vista presentes nas fontes, e que estende este reconhecimento na direção do historiador e já o aplica ao próprio sujeito que escreve a história. Esta posição ainda precisaria de algumas décadas para se tornar dominante entre os futuros

\footnotetext{
${ }^{5}$ Chladenius irá definir o que estará entendendo como ponto de vista: "aquelas circunstâncias da alma, do nosso corpo e de toda nossa pessoa, que fazem com que, ou são causa para que, representemos para nós alguma coisa desse modo, e não de outro, [nós as] queremos chamar de ponto de vista" (apud GRONDIN, 1991, p.106). É claro que, logo mais, a noção de "ponto de vista" se veria beneficiada também pela consideração das instâncias relacionadas a uma época, a um ambiente social e a uma posição social daquele que se coloca diante de algum fato da vida. Em Chladenius, na definição acima, isto está apenas implícito. Logo ocorreria maior delineamento desta noção. De todo modo, já temos com Chladenius a observação de que "a história constitui uma unidade em si mesma, mas que a sua representação é distinta e diversificada" (apud KOSELLECK, 2006, p.169).

${ }^{6}$ Ao que tudo indica, e tomando por base comentários do próprio Chladenius, teria sido Leibniz (1646-1716) o primeiro pensador a utilizar a expressão "ponto de vista" deslocada de seu contexto ótico e referida a um sentido geral que propõe o uso da expressão para simbolizar a diversidade de concepções em torno de uma mesma questão ou assunto. Hoje, este uso da expressão é corrente, e já não é percebido como a metáfora que foi um dia.

7 "Desse conceito ['ponto de vista'] decorre que aqueles que contemplam algo a partir de diferentes pontos de vista devem necessariamente construir representações diferentes desse objeto" (CHLADENIUS, 1741, p.185).
} 
historicistas, de modo que é particularmente notável encontrá-la em Chladenius em meados do século XVIII ${ }^{8}$. Com Chladenius inicia-se uma autêntica reflexão sobre as condições de produção do conhecimento histórico.

Obviamente que a perspectiva relativista possível a Chladenius tinha também que se deparar contra os seus próprios limites. A sua reflexão sobre a relatividade dos pontos de vista é a de um filólogo, mas ainda não a de um geógrafo ou de um historiador. Por isto, ele ainda aborda como uma "pessoa" - como uma "alma" com "corpo e circunstâncias" - o sujeito que se coloca no ponto nodal da perspectiva relativista. Mas não vai além, a ponto de perceber também a importância do "lugar" e do "tempo". Nos dias de hoje, quando se tem clareza de que as intersubjetividades inscrevem-se nesta tríade constituída pela "pessoa", pelo "lugar e pelo "tempo", ficamos com a impressão de que Chladenius apenas recobriu parte do problema. Mas logo surgiriam, ainda naquela segunda metade do século XVIII, outros filósofos e filólogos que completariam o insight relativista de Chladenius, atentando para as maneiras como o "lugar" e o "tempo" podem interferir no "ponto de vista". Thomas Abbt, na sua História do Gênero Humano (1766, p.219), já faz notar que o lugar faria a diferença, mesmo que se mantivesse invariável o povo ${ }^{9}$. Logo depois Gatterer (1768), Büsch (1775) e Schlözer (1784) - três autores da segunda metade do século XVIII que foram bem examinados por Koselleck - mostrariam que se encontra inscrita no "ponto de vista" também a perspectiva temporal. Schlözer chamará atenção para o fato de que "um determinado fato pode parecer, nesse momento, completamente irrelevante, e, cedo ou tarde, tornar-se decisivo para a própria história ou mesmo para a crítica" $\left(1784\right.$, p.7) ${ }^{10}$. Mas então, já estamos às portas do historicismo alemão.

Também será necessário observar que os autores que exploraram a idéia de uma perspectiva relativista para a História, naquela segunda metade do século XVIII, eram ainda pensadores mais ou menos isolados. Eles forneceram insights e materiais que só poderiam ser trabalhados mais sistematicamente pelos historiadores da Escola Alemã, já sob a perspectiva de uma postura metodológica que definirá os parâmetros da nova história científica. E, ainda assim, com relação ao reconhecimento da intersubjetividade do próprio historiador, haverá mesmo um certo recuo dos primeiros historicistas, tais como Ranke e Niebuhr, que ainda advogarão um

\footnotetext{
${ }^{8}$ É surpreendente encontrar em Chladenius uma passagem que muito se assemelha a um comentário de Droysen, um historicista que já adota um ponto de vista relativista a partir de sua obra Historik (1858). Mais de um século separa estes autores, mas vemos aqui Chladenius antecipar uma posição que só começaria a ser afirmada mais insistentemente com Droysen e outros historicistas das quatro últimas décadas do século XIX. Eis a passagem de Chladenius: "Estão muito equivocados aqueles que exigem que o historiador se comporte como um homem sem religião, sem pátria e sem família, pois exigem algo impossível" (CHLADENIUS, 1752 apud KOSELLECK, 2006, p.170). Eis a passagem de Droysen: "Eu não aspiro senão, nem mais nem menos, a deixar à mostra a verdade relativa ao meu ponto de vista. Quero mostrar como minha pátria, minhas convicções políticas e religiosas, meu estudo sistemático me permitiram chegar a este ponto de vista" (DROYSEN, 1858; edição: 1977, p. 235-236).

9 "A História de um mesmo povo será diferente na Ásia e na Europa" (ABBT, 1766, p. 219). Esta passagem, e as duas seguintes, são comentadas por Koselleck (2006, p.172) no seu ensaio sobre o "Ponto de Vista".

${ }^{10}$ Além desta passagem de Schlözer, Koselleck (2006, p.173) transcreve a seguinte passagem de Büsch: "Neste momento, acontecimentos que só agora se tornaram perceptíveis conferem importância a uma história que antes teria nos interessado muito pouco, ou que absolutamente não nos teria interessado" (BÜSCH, 1775, p.12).
} 
"historicismo realista". Eles estarão prontos a reconhecer a subjetividade do humano, mas especialmente no que concerne às fontes e às sociedades a serem examinadas pelos historiadores. Daí até aceitarem mais plenamente a subjetividade do historiador, e a concordarem em colocar em xeque a própria ambição de absoluta neutralidade por parte do historiador, terão que esperar pela contribuição dos historicistas da segunda metade do século XIX, que, tal como Droysen ou Dilthey, já representam uma vertente mais acentuadamente relativista do Historicismo. É somente então que o pleno relativismo historicista será retomado com maior vigor e plenitude, estendendo-se mais uma vez da percepção da subjetividade das fontes e das sociedades humanas para o reconhecimento da subjetividade que afeta o próprio historiador que elabora a História.

Há ainda outra questão relacionada a este breve mas importante ímpeto relativista que se estabelece no encontro da filologia de Chladenius, e de seus contemporâneos, com uma inovadora reflexão sobre a história. Pode-se dizer que a corrente relativista dos filólogos e eruditos setecentistas que podem ser bem representados pela figura de Chladenius constituiu uma espécie de "trovão" que anunciou a "tempestade" historicista que breve iria se impor aos meios historiográficos oitocentistas. Esta discreta corrente relativista da segunda metade do século XVIII, que percorre não muitos autores, foi para o Historicismo que estava por vir o mesmo que o movimento "Sturm und Drang" foi para o Romantismo do século XIX". O relativismo historicista é aqui prenunciado pelo ímpeto relativista de Chladenius e de outros eruditos alemães, tal como uma tempestade é preludiada por uma revoada de pássaros.

Este movimento só possuía um ponto problemático - uma espécie de "calcanhar de Aquiles" epistemológico - que o impedia de saltar efetivamente para um novo fazer histórico como aquele que logo seria alcançado pelo Historicismo a cargo da futura Escola Alemã. Chladenius e seus análogos (super)valorizavam as fontes oculares (testemunhos orais) em detrimento das fontes escritas; e com isso privilegiavam uma espécie de "história do tempo presente" em desfavor da história de dos tempos mais recuados. Somente quando esta tendência foi ultrapassada, e afirmou-se definitivamente a desvalorização da "testemunha ocular" e o declínio desta espécie de "história oral" (se pudermos, um tanto anacronicamente, chamá-la assim), é que "o passado deixou de ser mantido na memória pela tradição escrita ou oral, passando a ser reconstruído pelo procedimento crítico" (as últimas palavras são de Koselleck, 2006, p. 174). Esta aplicação de um método crítico ao exame de fontes escritas, fossem do passado mais remoto ou dos períodos menos recuados em relação ao presente do historiador, seria um ponto

\footnotetext{
${ }^{11}$ Explicaremos a nossa metáfora. O Sturm und Drang (“Tempestade e Ímpeto”) foi um movimento estético-literário alemão que vigorou entre os anos 1760 e 1780, em pleno período europeu de predomínio do classicismo iluminista. Correspondeu a uma espécie de excitação estética momentânea, que antecipou valores anti-classicistas que logo retornariam com todo vigor com o Romantismo oitocentista. A metáfora torna-se aqui oportuna. O Ímpeto relativista inaugurado por Chladenius não teve vigor suficiente para se contrapor ao universalismo iluminista, e propagou-se apenas através de uns poucos cérebros. Mas trouxe os primeiros sinais de uma nova perspectiva historiográfica que breve dominaria o mundo historiográfico através do paradigma historicista, embora contraponteado pela alternativa positivista.
} 
capital para o Historicismo vindouro. Somente com o pleno exercício deste procedimento crítico a história poderia começar a aprender a ser moderna.

Além do 'ímpeto relativista', o Historicismo em formação iria também recolher outro elemento disperso em meio às resistências anti-universalistas que já tinham começado a grassar na cultura européia do século XVIII. Referimo-nos à "crítica" que, não mais apenas voltada "esclarecidamente" contra os poderes instituídos e preconceitos de toda ordem, dirige-se também para uma auto-avaliação de cada disciplina que deve estender um olhar sobre si mesma. Na história da historiografia, já surpreenderemos na segunda metade do século XVIII estes primeiros sinais de um 'olhar sobre si', através do qual a historiografia submete a um atento exame o próprio trabalho dos historiadores. O sinal da autocrítica historiográfica já é visível em Johann Salomo Semler (1725-1791), um teólogo-historiador ligado à velha tradição da 'história teológica' - esta corrente historiográfica que teve seu apogeu no século XVII, com Bossuet (1681), mas que ainda se encontrará bem viva nos dois séculos seguintes. Semler queria aplicar um método histórico-crítico às ciências bíblicas, de modo a constituir o que ele mesmo denominaria "teologia liberal" (liberalis theologia) ${ }^{12}$. Mas a sua mais notável contribuição para a história da historiografia foi o reconhecimento da necessidade de empreender permanentemente uma elaboração crítica da historiografia anterior, o que deveria ser feito pelos próprios historiadores. Para ele, a historiografia era parte da história, e isto porque as mudanças impostas pela própria sucessão de momentos históricos ("tempos históricos") impunha que sempre surgissem novos historiadores, portadores de um novo olhar sobre os períodos anteriores ao seu presente.

Nos dias de hoje, ao menos nos meios acadêmicos que formam o historiador profissional, isto soa como um lugar comum. Mas devemos levar em conta que na segunda metade do século XVIII esta percepção era ainda um elemento disperso em meio às visões dominantes de que existia uma "verdade histórica" única da qual, tanto quanto possível, deveria ser seu speculo a reconstituição histórica a ser realizada pelos historiadores. A noção de que cada época produz a sua "verdade histórica" ainda soaria muito estranha para a maioria dos homens. A idéia hoje igualmente corriqueira de que é útil e necessário reatualizar constantemente uma história da historiografia, hoje convertida em disciplina solidamente estabelecida no currículo formativo dos historiadores, também soaria estranha na segunda metade do século XVIII. É precisamente esta estranheza que é confrontada por Semler, ainda em 1777, ao ressaltar que, até aquela época, "muito pouca atenção se tinha dado àquela história que procedeu a história de todos os assim chamados historiadores" (SEMLER, 1777, p.9) ${ }^{13}$. A este descaso, Semler confrontava a sua convicção de que seria imprescindível para os próprios historiadores este olhar para dentro da historiografia. Neste sentido, cada nova geração historiográfica deveria submeter as anteriores a

\footnotetext{
${ }^{12}$ Semler, embora fosse teólogo, trabalhava com a perspectiva de que Deus não intervinha na história humana, de modo que a sua 'história teológica' não vinha pontilhada por milagres; ao lado disto, propunha aplicar um método histórico-gramatical à interpretação de passagens do Antigo Testamento.

${ }^{13}$ Koselleck (2006, p.176-177) cita esta e outras passagens de Semler como indicativas de um momento importante na história do relativismo historiográfico.
} 
uma análise crítica, inclusive desmascarando interesses específicos que as tenha levado a produzir uma visão histórica e não outra ${ }^{14}$.

A prática historiográfica do "olhar sobre si", apenas casual e esporádica até meados do século XVIII, iria se tornar uma exigência da própria 'matriz disciplinar' da História. Em vista de sua predisposição relativista, o Historicismo, mais do que o Positivismo, sempre mostrou maior afinidade em relação a esta necessidade de reelaborar constantemente um 'olhar sobre si' que é constituinte da própria Teoria da História. Sua gênese, em fins do século XVIII e na passagem para o novo século, recolhe este elemento autocrítico conjuntamente com o 'ímpeto relativista', e os coloca a conviver com outra tradição que já vinha de uma longa origem: a 'crítica documental'. De uma prática rigorosa de avaliação de procedência e autenticidade de documentos escritos, que teve na De Re Diplomática (1709) do monge beneditino Jean Mabillon (1632-1707) o seu tratado de diplomática mais célebre, o Historicismo extrairá um terceiro elemento para o seu sistema paradigmático. Depois, a 'crítica documental' migraria para o próprio métier do historiador, seja qual fosse a sua escolha paradigmática ou a escola histórica de pertença. Mas, nos primórdios, não se pode negar que a incorporação à História de um rigoroso método de crítica documental foi uma contribuição original do Historicismo, a qual este já havia extraído de toda uma tradição diplomática anterior, desenvolvida sobretudo nos meios eclesiásticos ${ }^{15}$.

O Historicismo se formou, assim, de elementos dispersos. Aproveitou as técnicas de crítica documental que já vinham sendo desenvolvidas pelos teólogos, e também se valeu do ímpeto relativista inaugurado por Chladenius e outros filólogos. Da Hermenêutica, um saber técnico igualmente oriundo dos meios eclesiásticos, e que logo seria elevado a 'arte da interpretação', também extrairia um novo traço de identidade. O Historicismo em gênese cresceu ainda com a perda de valorização de um certo setor da prática historiográfica que se fundava na

\footnotetext{
${ }^{14}$ Admitir que cada época produz a sua própria "verdade histórica" já constituía uma novidade grande. Sobretudo no seio de um conhecimento teologicamente concebido, não seria possível a um historiador setecentista deixar de imaginar que, destarte, não haveria uma "verdade maior" da qual sempre se aproximar, e cada vez mais. Por isto, tal como faz notar Koselleck, Semler terminou por associar sua percepção relativista da história à noção de progresso que então começava a se afirmar soberanamente, levando-o a entender que a cada nova época estava mais habilitada (por Deus) para produzir um conhecimento histórico mais verdadeiro (KOSLLECK, 2006, p.177).

15 Não será o caso de recuperar aqui a história desta longa tradição, da qual o Historicismo irá apreender o necessário para os primeiros aspectos relacionados à análise documental. Podemos lembrar aqui alguns dos marcos importantes na história da Diplomática. Uma significativa linha de avanços na precisão e eficácia da crítica documental veio já se desenvolvendo no decurso do chamado período renascentista, e se afirmou com os grandes eruditos do século XVIII. A Igreja e a crítica teológica certamente trouxeram o seu importante quinhão para os progressos na crítica documental, e no século XVII destacar-se-iam nomes como os dos padres jesuítas Jean Bolland (1596-1665) e Daniel von Papenbroeck (16281714), que em 1675 publicaria um texto para os Acta Sanctorum no qual discorria "sobre o discernimento do verdadeiro e do falso nos velhos pergaminhos" (LE GOFF, 1990, p.543). Neste texto, Papenbroeck lançava dúvidas sobre alguns documentos atribuídos à época Merovíngia que estavam guardados nos arquivos da Ordem de São Bento - outro centro de crítica documental eclesiástica importante na época, e que rivalizava com os dos críticos jesuítas. Em vista disto, instalou-se uma verdadeira Guerra Diplomática entre estes dois setores eruditos da Igreja Católica, e o monge beneditino Jean Mabillon (1632-1707) resolveu replicar em 1681 com a obra De re diplomática, uma extensa obra em seis partes que pretendia estabelecer as regras fundamentais da diplomática (BELLOTO, 2002, p.15-16). Marc Bloch, em seu ensaio Apologia da História (1949, póstuma) eleva a obra de Mabillon ao status de acontecimento que funda a própria crítica moderna dos documentos de arquivos. Deste longo desenvolvimento, e adaptando-o a seus próprios fins, beneficiar-se-ia mais tarde o Historicismo.
} 
priorização de testemunhas oculares (esta proto-história oral), e tirou partido do conseqüente declínio daquela "proto-história do tempo presente" que vinha sendo cultivada por Chladenius e por alguns outros eruditos alemães. Todos estes aspectos foram importantes na gênese do Historicismo, que para criar uma nova história juntou elementos antes dispersos: 'ímpeto relativista', 'crítica documental', 'interesses temáticos voltados para todos os períodos históricos', 'autocrítica historiográfica', 'potencial interpretativo'. A isto agregou a potente onda de especializações que já clamava por ciências bem definidas em detrimento da prática multidisciplinar à qual se entregava a maior parte dos sábios iluministas. Por fim, o contexto de afirmação dos estados-nacionais só os favorecerá, aos novos historicistas, assim como também as afinidades com o Romantismo então nascente - um movimento estético que também valorizava os particularismos. Uma pedra de toque será trazida pela sua feliz adaptação àquela já mencionada prática de autocrítica que seria tão típica da segunda modernidade, levando cada campo de saber a intensificar as 'reflexões sobre si mesmos' (as "críticas" de Kant, este iluminista que já é, contudo, um espírito típico desta segunda modernidade, constituem claros sinais destes novos tempos) ${ }^{16}$.

Foi desta dispersão de vários elementos de origens diversas que se construiu algo novo: uma nova matriz historiográfica. Mistura-se tudo isto no efervescente caldeirão de "aceleração temporal" que foi detonado pelos acontecimentos políticos da Revolução Francesa e pela tecnologia que, a partir da sociedade industrial, não cessa de trazer inovações e a produzir rupturas regidas por barcos a vapor (1803), locomotivas (1804), fotografias (1823), telégrafos (1844), telefones (1860), iluminação elétrica (1879), automóveis (1885). Cada uma destas invenções e novidades, e todas elas em conjunto, produzem transformações diretas na vida prática, mas também nos modos de sentir e de pensar dos seres humanos, no seu imaginário, e nas próprias elaborações intelectuais daqueles que as viveram ${ }^{17}$. O novo século, sob o signo da aceleração do tempo provocada pelas transformações políticas e tecnológicas não poderia se tornar senão o "século da história"18. Eis aqui um esboço de gênese do Historicismo, que poderá a partir de então

\footnotetext{
${ }^{16}$ Em um dos prefácios de Immanuel Kant para a sua Crítica da Razão Pura (1781), este filósofo alemão afirmava: "nossa época é a época da crítica, à qual tudo deve se submeter". Esta nova predisposição, típica da segunda modernidade que principia com o século XIX, atinge obviamente a História. Neste caso, há ainda um reforço adicional que está implicado pelo próprio relativismo que tende a configurar o próprio olhar do historiador, ao menos de acordo com a perspectiva historicista (e mais tarde com a do Materialismo Histórico).

${ }^{17}$ Surgem, por exemplo, metáforas para compreender o "trem da História" em sua inabalável marcha pelos trilhos do tempo rumo à Estação do Futuro. A invenção da Fotografia, que irá abalar profundamente os ideais representativos da arte pictórica, também abre em contrapartida um novo leque de alusões metafóricas a serem empregadas pela ciência da história. Seria a História capaz de concretizar uma reprodução da imagem da realidade, tal como faz uma fotografia? A imagem da História como speculo pode adquirir a sofisticação da metáfora fotográfica, ao gosto positivista. Mas o próprio Karl Marx, impressionado pelo invento da fotografia, também ficou a imaginar se a sua concepção da "ideologia" como uma "inversão da realidade" não poderia ser beneficiada pela metáfora da fotografia, uma vez que as "câmaras escuras" dos fotógrafos também produzem "inversões de imagens" (a metáfora é empregada por Marx e Engels em Ideologia Alemã).

${ }_{18}$ Dirá Reinhart Koselleck (1979): "Essa temporalização de perspectivas foi certamente favorecida pelas rápidas transformações da experiência provocadas pela Revolução Francesa. Tais rupturas de continuidade pareciam querer livrar-se de um passado cuja crescente estranheza só poderia ser esclarecida e recuperada pela pesquisa histórica" (KOSELLECK, 2006, p.174). É o mesmo Koselleck, aliás, quem recolhe este impressionante depoimento de Friedrich Perthes (1772-1843) sobre a sensação de descontinuidade nos novos tempos oitocentistas: "Nosso tempo reuniu nas três gerações,
} 
desenvolver suas alternativas internas por sobre esta tensão essencial entre um mundo em acelerada transformação, que se faz acompanhar de intensas expectativas em relação ao futuro, e um ambiente acadêmico que cedo se põe a serviço de um sistema político conservador, ao menos no caso da Escola Histórica Alemã.

Antes de prosseguirmos, valerá a pena insistirmos em alguns dos outros precursores do Historicismo que já podemos surpreender em pleno século iluminista, e mais particularmente no quadro artístico-intelectual dos românticos. Aqui devemos lembrar que Johan Gottfried von Herder (1744-1803) já antecipara a perspectiva particularizante do Historicismo em 1774, em seu ensaio Mais uma Filosofia da História. Nesta obra, o filósofo alemão já chamava a atenção para a particularidade de cada povo, de cada tradição, de cada realidade nacional, e se punha na contracorrente do universalismo iluminista, tornando-se o principal representante da filosofia romântica da História no final do século XVIII:

cada forma de perfeição humana, é, num certo sentido, nacional e temporalizada, e, considerada de modo mais específico, individual ${ }^{19}$

Antes de Herder e dos românticos do final do século XVIII, seria importante ressaltar também as antecipações de Vico (1668-1744), que em Ciência Nova $(1725 ; 1744)$ já desenvolvia uma perspectiva voltada para a apreensão da singularidade de cada povo, ainda na primeira metade do século XVIII. Vico já chamava atenção para as ilusões de unidade que podiam assaltar os estudiosos das sociedades humanas ao tomarem a si mesmos, e às suas sociedades, como uma medida para todas as coisas.

Por causa da natureza indefinida do espírito humano, onde quer que esteja perdido na ignorância, o homem faz de si mesmo a medida de todas as coisas (VICO, 1953, p.120).

que agora convivem, coisas inteiramente incompatíveis. Os enormes contrastes dos anos 1750, 1789 e 1815 carecem completamente de transições, aparecendo aos homens que vivem hoje, sejam eles avós, pais ou netos, não como uma sequência de acontecimentos, mas sim como simultaneidades" (PERTHES, 1815, p.320). Perthes escreveu isto pouco depois de 1815, após a queda de Napoleão. Ainda não tinham ocorrido, portanto, as revoluções de 1830 e de 1848, e nem a Comuna de Paris, em 1871. Se tivesse vivido cem anos, teria ainda presenciado mais descontinuidades. De todo modo, a Perthes, pareceu assombrosa a aceleração temporal das últimas décadas do século XVIII e das primeiras décadas do século XIX, a tal ponto que ele chegou a afirmar: "De uma história que está sendo escrita agora não se pode esperar nada permanente, nenhuma história real".

${ }^{19}$ É também Herder quem nos dirá: "cada nação tem em si o seu centro de felicidade, como cada esfera o seu centro de gravidade" (HERDER, 1995, p.42). Por outro lado, mesmo a filosofia da história de Herder é impregnada do otimismo teleológico recorrente entre os iluministas, como se pode ver na seguinte passagem: "Trata-se pois verdadeiramente de avançar, de progredir, de desenvolvimento progressivo, ainda que nenhum homem particular tivesse ganho com isso! $O$ processo dirige-se para algo de maior! Torna-se o palco de uma intenção condutora na terra! Ainda que dessa intenção não consigamos enxergar a intenção última. Palco da divindade, ainda que só possamos vê-los por entre as aberturas e os destroços de cenas particulares" (HERDER, 1995, p.46). 
Em vista da visão historiográfica atenta às singularidades humanas que já era trazida por nomes como Vico e Herder, fala-se também em uma historiografia romântica, tanto com referência aos poucos precursores do particularismo historicista no século XVIII, como em referência a alguns dos pensadores românticos do século XIX. Eles não diferem muito dos historicistas propriamente ditos. Um dos poucos pontos de contraste é o fato de que a historiografia romântica preconizava um método intuitivo para a construção do conhecimento histórico, ao contrário do rigoroso método de crítica documental que já ia sendo encaminhado pelos historicistas de inspiração alemã. Também os literatos românticos, e os artistas românticos de maneira geral, apresentavam muitas afinidades com o Historicismo, particularmente no que se refere à sua nostalgia do passado gótico, à sua revalorização da Idade Média, e à rejeição das abstrações racionalistas que haviam sido encaminhadas pelos iluministas do século XVIII. Isto posto, consideraremos aqui uma corrente única, sem discutir as especificidades da variação romântica do historicismo, e falaremos apenas do Historicismo de modo geral, por oposição ao positivismo de sua própria época.

Voltando ao século XIX, pode-se dizer que o paradigma Historicista, desde a contribuição de um Ranke que ainda parece afirmar possibilidade de "contar os fatos tais como eles se sucederam", foi abrindo cada vez mais espaço para o relativismo histórico, para a consciência da radical historicidade de todas as coisas, mergulhadas que estão no interminável devir histórico ${ }^{20}$. O Historicismo, em diversos de seus setores, foi apurando a percepção de que o historiador não pode se destacar da sociedade como pressupunha o modelo das ciências naturais preconizado pelo Positivismo e outras vertentes cientificistas das ciências humanas. Ao contrário disto, foi se afirmando cada vez mais, no universo historicista, a idéia de que o historiador fala de um lugar e a partir de um ponto de vista, e que, portanto, não pode almejar nem a neutralidade nem a objetividade absolutas, e menos ainda falar em uma verdade em termos absolutos. A Hermenêutica - campo de saber dedicado à interpretação de textos e objetos culturais - foi se afirmando como importante espaço de reflexão a partir de filósofos e historiadores que realçavam a relatividade dos objetos, sujeitos, e métodos históricos.

Para que o historicismo, de modo geral, abrisse espaço para um setor da historiografia alemã que encaminharia esta virada relativista em todos os seus aspectos, seria preciso percorrer um longo caminho. De fato, ao se examinar a obra de diversos dos historicistas oitocentistas,

\footnotetext{
${ }^{20}$ Mesmo com relação a Ranke, têm surgido polêmicas em torno da pretensa neutralidade rankeana, concluída apressadamente a partir do célebre dito "wie es eigentlich gewesen". Josep Fontana, em seu livro A História dos Homens (2000) retoma uma discussão levantada por Gooch (1968) e procura mostrar que Ranke se integra com plena consciência aos interesses do estado prussiano e ao projeto de combater idéias revolucionárias, o que é encaminhando pela Revista Histórica-Política, por ele dirigida. Assim, Josep Fontana desfecha a sua análise do contexto pessoal de Leopold Von Ranke: "Nada que se assemelhe a 'explicar as coisas como tal e como aconteceram' e, muito menos ainda, no 'divórcio das paixões do presente'. Ranke foi um funcionário ideológico do estado prussiano, útil, serviçal e consciente do papel que lhe correspondia desempenhar" (FONTANA, 2004, p.226-227). Segundo Gooch, o dito de Ranke mais se referiria a uma expressão de modéstia do que a qualquer outra coisa.
} 
podemos identificar em alguns deles traços que de alguma maneira parecem lembrar os ideais positivistas de neutralidade. Para se compreender isto, é preciso ter sempre em conta que - ao contrário do Positivismo, que praticamente já estava formado na primeira década do século XIX em virtude de ter herdado do Iluminismo os seus principais traços paradigmáticos (embora os aplicando para um uso conservador) - já o Historicismo irá construir passo a passo o seu paradigma no decurso do século XIX. Isto explica que, à partida, o Historicismo Alemão, ou ao menos uma de suas escolas, a rankeana, ainda apresente claramente posições conservadoras, sempre a serviço dos grandes estados-nacionais, e neste novo contexto é bastante interessante notar que Ranke ainda declara ser capaz de "contar os fatos tais como eles se deram" (se bem que haja bastante polêmica em torno do verdadeiro sentido deste dito). De todo modo, Ranke já não crê em uma história universal humana, e sim em histórias nacionais particulares, de maneira que já se vê aqui um primeiro princípio de aceitação da relatividade historiográfica - neste caso ao nível do objeto de estudo.

Diga-se de passagem, é importante se ter em vista que, embora possamos agregar sobre a rubrica do Historicismo Alemão uma série de historiadores de origem germânica que se empenham em encaminhar o novo paradigma historicista, podem ser percebidos, por outro lado, setores historiográficos diferenciados no interior deste paradigma. Júlio Bentivoglio, ao debruçar-se sobre esta questão, demonstrou com eficácia a presença de duas escolas no interior do Historicismo Alemão oitocentista: a escola rankeana, e a escola prussiana, que começa a se fortalecer em um dos setores historiográficos da Universidade de Berlim desde meados dos anos 1840, passando a se organizar em torno de expoentes como Gervinus (1837) e mais tarde Droysen, até culminar com a criação da Revista Histórica em 1859 por Heinrich Von Sybel (BENTIVOGLIO, 2010, p.22) ${ }^{21}$. Esta segunda escola - a prussiana - fará uma atenta crítica à escola rankeana primordial (mas sendo que a própria escola rankeana não se extinguirá, seguindo na verdade em paralelo à escola prussiana no decorrer da segunda metade do século XIX). Em nossa análise mais preocupada com a percepção dos traços essenciais do paradigma historicista - a escola prussiana, ao lado dos filósofos de Baden, corresponderá ao braço mais relativista do historicismo alemão. De todo modo, pode-se dizer que o paradigma historicista abrange tanto a escola rankeana como a escola prussiana (se adotarmos a terminologia de Bentivoglio), sobretudo quando o contrapomos ao paradigma positivista.

Retornemos, portanto, ao fato de que o Historicismo irá se confrontar contra a concepção iluminista-positivista de uma natureza universal do homem histórico - esta que acena concomitantemente para viabilidade de uma história universal humana - para produzir, ao contrário, uma perspectiva de construção de histórias nacionais particulares que busque

\footnotetext{
${ }^{21}$ A crítica da escola prussiana contra a tendência rankeana é todavia sutil e complexa. Bentivoglio contrapõe-se aos comentários de Robert Southard (1995), que ressaltara que, para nascer, a Escola Histórica Prussiana precisou superar o interdito rankeano de neutralidade e de "não-envolvimento direto do historiador nos assuntos da política" (BENTIVOGLIO, 2010, p.31). O historiógrafo brasileiro procura mostrar que mesmo a Ranke não era possível, nos quadros do contexto estatal alemão, não se envolver de alguma maneira com a política de seu tempo.
} 
apreender a especificidade de cada povo e de cada conjunto de circunstâncias ${ }^{22}$. Em nossa perspectiva, este é de fato o traço fundamental que perpassa a atitude historicista, a "cor geral" que o atravessa e ilumina tudo o mais, produzindo outros desdobramentos ${ }^{23}$. O Historicismo é pioneiro ao apresentar uma nova perspectiva sobre o Homem, bem distinta da perspectiva que era no século anterior apresentada pela tendência dominante pelo pensamento ilustrado, e que em seu próprio século continuaria a ser sustentada pelo Positivismo. Naquele "Homem" que os iluministas e os positivistas procuravam enxergar como universal e caracterizado por uma natureza imutável, os historicistas já começam a enxergar a diferença, o movimento. Em uma palavra: a historicidade. O Homem (ou os homens) e as sociedades humanas são realidades em movimento, e assim devem ser percebidos. Ao invés de buscar o universal, a atitude historicista busca perceber a diferença, a singularidade, o específico, o singular, o particular. Ao invés de estar obcecada pela descoberta da natureza imutável do homem, a concepção historicista deleitase, e mesmo embriaga-se, com a percepção do movimento. Em uma palavra, trata-se de apreender com radical historicidade toda e qualquer realidade, de modo que nada no universo estaria estático e imobilizado, ao mesmo tempo em que nenhuma coisa seria igual a outra neste interminável devir histórico.

Esta cor geral, que constitui no Historicismo um olhar atento à diversidade e à mutabilidade, produz os seus imediatos desdobramentos. Um século, no entanto, é apenas um breve momento na construção de um novo paradigma historiográfico, e por isso não devemos estranhar que este modelo não tenha se apresentado pronto desde o primeiro momento. Foram precisas décadas de história e de historiografia para que os historicistas, no seu conjunto, explorassem radicalmente todas as implicações de sua nova atitude em favor da diferença e do movimento. O historicismo oitocentista, a longo termo, só terminou por se construir integralmente a partir da apurada crítica desenvolvida pela escola prussiana de Droysen (1868) contra a escola rankeana, sem contar a imprescindível contribuição dos importantes ensaios sobre as ciências humanas desenvolvidos por Dilthey (1883) e a influência da Escola de Baden liderada por Windelband (1894) e Rickert (1899) ${ }^{24}$. De modo geral, poderemos resumir três

\footnotetext{
${ }^{22}$ As histórias nacionais produzidas pelos historicistas são já bem diferenciadas de uma história nacional como a História da Inglaterra de David Hume (1754), filósofo escocês que acompanha o investimento iluminista na idéia de uma natureza universal do homem histórico. Ver ainda Hume (1734).

${ }^{23}$ É importante, de outra parte - e ao lado da possibilidade de identificar traços gerais que poderiam caracterizar o Historicismo como um paradigma em formação no século XIX - reconhecer toda uma diversidade interna ao Historicismo. Para um estudo desta diversidade, são referências bastante significativas algumas obras escritas nas últimas décadas: Reill (1975); Hardtwig (1982, p.147-181); Jaeger e Rüsen (1992); Muhlack (1991); Wittkau (1992), bem como os textos das coletâneas organizadas por BLANKE (1994) e conjuntamente por Blanke e Rüsen (1984), abarcando um recorte que vai da historiografia iluminista ao Historicismo. Para uma análise sob a perspectiva do Materialismo Histórico (JAMESON, 1979).

${ }^{24}$ No âmbito da filosofia e da ciência política, a Escola de Baden desenvolve-se por contraposição à Escola de Marburg. Esta sustentava que o conhecimento se condiciona exclusivamente à apreensão do genérico. Enquanto isso, a Escola de Baden afirmava que, ao lado do conhecimento do genérico, existia também o conhecimento do particular. Por isto, as ciências matemático-naturais não seriam as únicas possíveis, tal como pretendiam os filósofos de Marburg (Cohen e Natorp), afirmando-se também as ciências históricas. Este ponto de vista acha-se perfeitamente sintonizado com as pretensões historicistas, que apontavam para uma concepção da História como ciência do particular.
} 
princípios fundamentais que essencialmente sustentam este paradigma historicista em construção.

O paradigma historicista completo, este é o ponto, principia enfaticamente com (1) o reconhecimento da 'relatividade do objeto histórico'. De acordo com este princípio, inexistem leis de caráter geral que sejam válidas para todas as sociedades, e qualquer fenômeno social, cultural ou político só pode ser rigorosamente compreendido dentro da história. A historicidade do objeto examinado (uma sociedade humana, por exemplo, mas também uma vida humana individual, ou qualquer evento ou processo já ocorrido ou em curso) deve ser o ponto de partida da investigação - e não, como propunha o Positivismo, a universalidade das 'sociedades humanas' ou a unidade fundamental do comportamento humano. Apreender com radical historicidade toda e qualquer realidade, seja esta uma realidade social ou natural (ou as duas coisas) será aqui a palavra de ordem historicista: o ponto cego do qual tudo se origina.

Em segundo lugar (2), a História, bem como as demais ciências humanas, deveria requerer uma postura metodológica específica, radicalmente distinta do padrão metodológico típico das ciências naturais ou das ciências exatas. Formulava-se aqui a distinção entre dois tipos de ciências - ou, em outras palavras, o direito de que um outro tipo de conhecimento postulasse cientificidade sem que necessariamente o seu modelo coincidisse literalmente com o das ciências da natureza. Logo surgiria, a partir desta formulação, a célebre oposição entre a "compreensão", atitude que deveria reger o posicionamento metodológico nas ciências humanas, e a "explicação", que seria típica das ciências naturais e exatas. Na base desta distinção, seria possível falar em uma diferença fundamental entre fatos históricos e fatos naturais. Por fim (3), o Historicismo estaria pronto a reconhecer a 'subjetividade do historiador', assumindo todas as implicações da idéia de que também o historiador ou o cientista social encontra-se mergulhado na história, o que faria da ambição positivista de alcançar a total "neutralidade do cientista social" não mais do que uma quimera.

Os três traços acima indicados como essenciais do pensamento historicista mais completo são, ainda, beneficiados por uma 'perspectiva particularizante' que se torna bastante típica do Historicismo, por oposição à 'perspectiva generalizante' que era característica tanto da maior parte do Iluminismo do século XVIII como do Positivismo oitocentista. Se estas correntes buscavam frequentemente encontrar 'leis gerais' para a explicação dos comportamentos e desenvolvimentos das sociedades humanas, já o Historicismo, de modo geral, abre mão desta busca, e procura se concentrar no particular, naquilo que torna cada sociedade singular em si mesma, nos aspectos que fazem de cada processo histórico algo específico ${ }^{25}$.

\footnotetext{
${ }^{25}$ É interessante conferir os comentários de Grondin (1991, p.143) acerca das relações da particularização buscada pelo historiador (historicista) com o todo, do qual emerge o particular, e, inversamente, "o todo a partir do particular, no qual ele se expressa". Temos aqui, nesta relação complexa entre particularismo e totalidade, um traço importante do paradigma historicista.
} 
Eis, portanto, a tríade do pensamento historicista: (1) relatividade do objeto histórico, (2) especificidade metodológica da história, e (3) subjetividade do historiador ${ }^{26}$. Trata-se, esta é a questão, de uma tríade conquistada aos poucos, pois o paradigma historicista foi se construindo no decurso do século XIX. Assim, desligando-se à partida das antigas propostas iluministas, e confrontando-se com o positivismo de sua própria época, cada vez mais o pensamento historicista iria investir na idéia de que as ciências humanas deveriam buscar métodos próprios, e não procedimentos emprestados às ciências da natureza. Logo surgiria a hermenêutica para opor a "explicação", própria das ciências naturais, à "compreensão", postura metodológica específica das ciências humanas. E, por fim, nas últimas décadas do século XIX, alguns setores historicistas completam a sua virada relativista: já acreditam que também o historiador, e não apenas as sociedades examinadas, está visceralmente implicado em toda a sua singularidade. Quando se chega a este ponto, Positivismo e Historicismo já se espelham perfeitamente com relação aos principais aspectos que se referem à relação entre objetividade e subjetividade historiográfica.

\section{A gradual instalação do Paradigma Historicista}

Uma vez que já vimos como o Historicismo conseguiu ser formado a partir de elementos dispersos que passaram a adquirir um novo sentido nos quadros da prática historiográfica, teremos agora a oportunidade de examinar como se foi instalando triunfalmente este paradigma historicista na Europa do século XIX, desde os seus primórdios, como uma alternativa que começa a se colocar frontalmente contra o Positivismo. O ponto de partida contextual de implantação acadêmica do Historicismo, conforme já ressaltamos, não deixou de ser tão conservador quanto o do Positivismo. Também os historicistas foram convocados para elaborar um novo modelo historiográfico que renunciasse à crítica social que um dia havia sido a tônica do discurso dos filósofos mais radicais da Ilustração. No caso do historicismo de inspiração alemã, os seus financiadores são os estados-nacionais (FONTANA, 2000, p.223) ${ }^{27}$. Assim, no caso

\footnotetext{
${ }^{26}$ Vale a pena também cotejar a análise de Schulz (1977, p.470). Este autor empresta uma maior abrangência ao conceito de Historicismo, encarando-o como espécie de uma virada epistemológica na história do pensamento ocidental, que, em favor da historicidade, ultrapassa os modelos dominados pela perspectiva metafísica. De fato, para Schulz, os traços centrais do historicismo correspondem a (1) rompimento com a metafísica; (2) a já mencionada busca de um método próprio por contraposição às ciências naturais e (3) a remissão à interioridade. Sobre a proposta de Schulz, ver CALDAS, 2007, p.50. Quanto à idéia de que a consciência histórica representa um rompimento em relação à Metafísica, este argumento também é sustentado por Gadamer (2008, p.3, v.2).

${ }^{27}$ Josep Fontana cita uma passagem de Ranke que bem ilustra sua posição conservadora e conciliadora de classes, de acordo com os interesses do estado prussiano. De acordo com esta passagem, a finalidade da História seria a de "abrir o caminho para uma política sadia e acertada, dissipando as sombras e os enganos que, nos tempos em que vivemos, obscurecem e fascinam as mentes dos melhores homens" (RANKE, 1979, p.516-517). Também Charles Beard, historiador norte-americano ligado à corrente "presentista", já havia feito em 1943 uma crítica sistemática sobre a parcialidade de Ranke em favor do conservadorismo, mencionando no artigo That Noble Dream a análise do historiador alemão sobre a vitória alemã nas guerras franco-prussianas (1870-1871) como uma "vitória da Europa conservadora contra a Revolução", ou ainda a posição de Ranke em favor de Guilherme da Prússia na sua luta contra uma constituição mais democrática
} 
da Alemanha, Theodor Mommsen (1874) já assinalava no próprio século XIX, com especial clareza, o entrelaçamento entre o desenvolvimento da ciência histórica alemã e o processo de unificação política (BENTIVOGLIO, 2010, p. 23).

Diga-se de passagem, é importante notar que há leituras diferenciadas sobre a formação e natureza do Historicismo. Se atrás indicamos o Iluminismo como origem do Positivismo, este último já configurado como uma corrente que dá um destino conservador a certos pressupostos que haviam sido colocados pela primeira vez pelo pensamento Ilustrado, há também leituras que procuram vincular o Historicismo ao passado ilustrado. É o caso, por exemplo, da análise de Meinecke (1862-1954), ele mesmo um historicista, e que em seu ensaio de 1936 sobre $O$ Historicismo e seu Gênesis considera o Historicismo como se estivesse em linha de continuidade em relação à Ilustração, sendo que na passagem da Ilustração ao Historicismo teria ocorrido uma substituição da tendência à "generalização" por um "processo de observação individualizadora" (MEINECKE, 1982, p.12). Trata-se de uma interpretação problemática, uma vez que a generalização e a perspectiva universalizante eram traços muito fortes do Iluminismo, de modo que a sua supressão por uma visão particularizante é já certamente uma ruptura.

Outro ponto de complexidade é a migração intelectual de um campo a outro. Jorge Navarro Perez, em seu ensaio sobre A Filosofia da História de Wilhelm Von Humboldt (1996), procura mostrar como o lingüista e fundador da Universidade de Berlim - Wilhelm Von Humboldt (17671835) - teria passado da busca ilustrada das leis do progresso para uma perspectiva que passava a sustentar que era preciso avaliar cada época conforme a sua individualidade. Esta migração de idéias também pode ser percebida nos Escritos de Filosofia da História de Wilhelm Von Humboldt (1997).

Também é oportuno lembrar que o Historicismo, com seu novo paradigma particularizante, influenciou já na sua época outros campos do saber, para além da História, como foi o caso do Direito e da Economia. No primeiro caso, surgiria uma Escola de Direito Alemã que, através de nomes como o de Friedrich Karl von Savigny (1779-1861), rejeitava o universalismo implícito na teoria do jusnaturalismo, em favor da busca da singularidade histórica do conjunto de leis de cada povo. No caso da Economia, a influência historicista iria contribuir para a formação, na segunda metade do século XIX, de uma escola alemã de história econômica que passaria a empreender o estudo comparado de casos específicos e que teria em Schmoller (18381917) um de seus principais nomes.

Retornando aos aspectos paradigmáticos do Historicismo, é oportuno destacar a sua ligação estreita, ou pelo menos prioritária, com uma História (da) Política (isto é, uma História da Política ainda no sentido estreito, exclusivamente referente ao âmbito do Estado e do confronto entre Estados). De fato, os livros de Ranke - principal representante do historicismo alemão de 
primeira geração - têm sempre como tema central as relações que se estabelecem entre os estados, sejam através da guerra ou da diplomacia $(1824,1833)$. As nações, em Ranke, são sempre compreendidas no interior dos estados; este será um tema particularmente importante para os historicistas, conforme mostrou Wolfgang Mommsen (1996, p.5-28) em seu estudo sobre a transformação da idéia de nação na historiografia alemã. Para além disto, trata-se de uma história das elites, ou dos povos conduzidos pelas elites, e há certamente numerosas passagens rankeanas em torno daquilo que se convencionou chamar de "História dos Grandes Homens". Sintomaticamente, Ranke escreveu uma História dos Papas (1836) e uma História de Frederico o Grande (1878). A História (da) Política elaborada pelo historicismo alemão de inspiração rankeana é também uma História (dos) Políticos. Não faltam retratos pessoais dos reis, descrições da corte e menções aos ministros e demais políticos ${ }^{28}$.

Deve-se notar, neste quadro tendencial, que o Historicismo não tardaria a se partir em dois ramos bem diferenciados: um historicismo mais conservador - tanto politicamente como epistemologicamente - e um historicismo mais avançado no que concerne à assimilação do relativismo. Na primeira metade do século XX, o setor mais conservador do historicismo, através da figura dos seus herdeiros ou da memória de seus fundadores, passaria a sofrer rigoroso ataque de escolas históricas mais modernas, como a Escola dos Annales na França ou a escola presentista norte-americana. Este setor mais conservador do Historicismo é aquele que praticamente se imobiliza na contribuição de Ranke, quase se ossificando em um aspecto do seu "realismo historicista" e não chegando a completar a virada relativista que iria trazer ao historiador a plena consciência de sua própria historicidade. É este historicismo mais retrógrado, que conserva talvez traços difusos de positivismo, que se tornará um alvo fácil para os célebres artigos de Lucien Febvre em Combates pela História (1953), na fase de ascensão do movimento dos Annales ao espaço institucional francês.

Quanto ao setor do historicismo que fora tocado pelo sopro da renovação - ou por aquele mesmo ímpeto relativista que um dia soprara sobre intelectuais setecentistas como Chladenius, Abbt e Herder - pode-se dizer que este "historicismo relativista" completa definitivamente a virada relativista através de nomes como o de Johann Gustav Droysen (1808-1884) ou de Wilhelm Dilthey (1833-1911), destinando-se a seguir adiante através da vigorosa e criativa contribuição de filósofos e historiadores que bem mais tarde incluirão os nomes de Hans-Georg Gadamer (19002002), Paul Ricoeur (1913-2005) e Reinhart Koselleck (1923-2006). Mas antes de se chegar a estas notáveis contribuições, uma peculiar história precisou ser percorrida. É mesmo bastante curioso o fato de que, enquanto o iluminismo revolucionário se desenvolveria até atingir seu ponto de inflexão e se transformar no positivismo conservador, já o Historicismo nasce demarcado por

\footnotetext{
${ }^{28}$ Josep Fontana, no capítulo relacionado ao Historicismo de História dos Homens, ilustra esta questão com uma breve síntese sobre uma obra de 1827 que Ranke dedica à Monarquia Espanhola dos séculos XVI e XVII (RANKE, 1946; FONTANA, 2004, p.227).
} 
interesses conservadores e mesmo reacionários, mas termina por se desenvolver inexoravelmente rumo às mais avançadas propostas do historicismo relativista ${ }^{29}$.

O extraordinário sucesso do historicismo já desde meados do século XIX deve ser reputado aos inegáveis progressos relacionados à crítica das fontes, que em um primeiro momento foram implementados por historiadores como Leopold von Ranke (1795-1886) e Barthold Georg Niebuhr (1776-1831), e que depois continuam a ser desenvolvidos por historiadores como Johann Gustav Droysen (1808-1884). Enquanto os historiadores positivistas tendiam a se aproximar ingenuamente das fontes históricas, como se estas fossem mero depósito de informações, as quais bastaria aos historiadores extrair da documentação como se estivessem diante de uma mina de pedras preciosas, já os historicistas começam a questionar a dimensão de subjetividade que perpassa todas as fontes, e a se esmerarem em tirar partido destas dimensões intersubjetivas das fontes, sem considerá-las como limites indesejáveis ou mesmo intransponíveis. A noção de que existe o "fato histórico puro", visto à maneira positivista como um material que reside imobilizado na fonte e que deve ser resgatado pelo historiador nesta forma pura, passa a ser cada vez mais confrontada pelos historicistas. Johann Gustav Droysen, em um texto escrito em 1858 que mais tarde foi incluído na edição de sua Historik, procura mostrar que, se as fontes trazem referências objetivas a acontecimentos que foram presenciados ou a informações em geral, elas também são interferidas pelo imaginário da época e pela imaginação do historiador:

[a crítica das fontes, além disso, precisa distinguir:] 1) qual coloração geral ela [a fonte] recebeu do imaginário dominante na respectiva época e lugar (por exemplo, a coloração demonológica no século XV, o esnobismo epigônico na época alexandrina); 2) qual tonalidade particular pertence ao próprio autor da fonte, por suas inclinações, sua formação, seu caráter, etc (DROYSEN, 2009, p.52).

Droysen, é claro, está neste momento se referindo a fontes autorais - isto é, fontes que foram produzidas por um autor, e que podem ser de inúmeros tipos: cartas, decretos, discursos políticos, relatórios institucionais, relações produzidas por governantes ou funcionários oficiais, relatos de viagem, crônicas, romances, ensaios, poemas, depoimentos, declarações, bulas papais e

\footnotetext{
${ }^{29}$ Sobre o contexto historiográfico que, na Alemanha de fins do século XIX, favorece a tendência relativista e a projeção de todo um setor progressista do historicismo, e não mais conservador, podemos lembrar a análise de Michel Löwy: "Perto do fim do século XIX, o historicismo alemão começa a mudar de caráter: o próprio ponto de vista conservador aparece como historicamente superado. O desenvolvimento industrial gigantesco e acelerado da Alemanha, a unificação nacional do país no quadro de um estado constitucional, a penetração do capital no conjunto das relações econômicas e sociais, e o avanço de uma poderosa burguesia industrial e financeira aparecem mais e mais como fenômenos irreversíveis, que tornam anacrônica toda adesão às instituições, valores e formas de sociabilidade pré-capitalistas [...] 0 historicismo tende, portanto, a se redefinir e a se transformar em um questionamento de todas as instituições sociais e formas de pensamento como historicamente relativas; ele deixa de ser conservador para se tornar relativista" (LÖWY, 1994, p.70).
} 
tantas outras possibilidades. Mas a crítica também deve se voltar, de maneira não-ingênua, contra fontes de outros tipos, mesmo aquelas que parecem trazer informações em estado bruto, como boa parte da documentação de arquivo. Para o Historicismo, e para o desenvolvimento mais sistemático de uma historiografia científica, foi fundamental essa percepção de que a subjetividade humana interfere na produção da fonte desde o princípio, e de que, portanto, o historiador deve examinar o contexto de produção de todo e qualquer documento, as suas conexões, as singularidades daqueles que o registraram ou que nele interferiram. Mais adiante, em outra parte do seu texto, Droysen dirá: "no mundo ético [isto é, no mundo histórico, nada existe que não tenha sido mediado” (DROYSEN, 2009, p.53). Essa mediação deve ser uma parte tão importante da análise historiográfica como a própria informação que possa ser eventualmente extraída de um documento ${ }^{30}$.

A tendência positivista ou metódica de tratamento das fontes é hoje associada a uma ingenuidade incompatível com os desenvolvimentos historiográficos atuais. Relembremos o manual de Introdução à História Louis Halphen (1946) que, já contemporâneo aos primeiros tempos dos Annales, sugere que o historiador apenas precisaria esperar de suas fontes que estas "deixassem os fatos se apresentarem por si mesmos" ${ }^{31}$. Essa predisposição deriva de certo modo de uma concepção de ciência bastante própria do Positivismo, que consistia em acreditar que a ciência deveria se limitar, "antes de qualquer outra operação, a descobrir os 'fatos' para em seguida organizá-los 'cientificamente”" (ARÓSTEGUI, 1995, p.119). Neste mesmo espírito, Seignobos e Langlois buscavam dividir a operação de reconstrução do processo histórico em uma primeira fase que seria a Crítica, e uma segunda fase que seria a da "construção histórica", aqui tomada mais no sentido de "reconstituição histórica". Ou seja, eles não parecem preocupados em dar a perceber que, já desde o primeiro momento de contato com a fonte, o historiador precisa enfrentar a questão da interpretação histórica. Além disso, ainda avaliam o trabalho do historiador em termos de uma "reconstituição histórica", e não nos termos de uma "reconstrução histórica", que corresponde à nuance que emerge da consciência historicista acerca das intersubjetividades que afetam todos os momentos da operação historiográfica.

Enquanto os positivistas oitocentistas de todas as partes da Europa e os metódicos franceses produziam seus manuais historiográficos, os historicistas, desde Ranke, também não cessaram de refletir sobre o uso historiográfico das fontes, e logo passaram dos textos que antes vinham embutidos no prólogo ou nos apêndices de grandes obras historiográficas - como na História dos Povos Românicos e Germânicos escrita por Ranke em 1824 - para manuais específicos que procuravam teorizar e fixar metodologias com vistas à reconstrução do processo histórico. Um ponto alto destas realizações, além da Historik de Droysen, seria por exemplo o manual de

\footnotetext{
${ }^{30}$ Sobre Droysen, ver a tese de Pedro Spínola Caldas (2004).

${ }^{31}$ Assim se expressa, Halphen (1946, p.50): "Basta deixar-se de algum modo levar pelos documentos, lidos um após o outro, tal como se nos oferecem, para ver a corrente dos fatos se reconstituir quase automaticamente". Este trecho mostra que, mesmo no século XX, ainda seria possível encontrar amplos setores da comunidade historiográfica com uma perspectiva ingênua das fontes. O trecho citado, inclusive, foi alvo das severas críticas de Braudel contra a "historiografia metódica", no artigo de 1958 sobre "A Longa Duração".
} 
Bernheim, publicado em 1889. Esta obra é particularmente importante porque ilustra bem a distância do Historicismo em relação ao Positivismo: já discute o "conceito de História", e também se dedica a examinar "a concepção histórica de nosso tempo". Dito de outra forma, Bernheim já compreende o desenvolvimento da própria historiografia dentro de um plano de historicidade. De igual maneira, a perspectiva sobre a análise das fontes não está aqui mais aprisionada pela ingenuidade positivista.

Colocando-se em uma perspectiva mais rica no que se refere à análise da documentação historiográfica, não é de se estranhar que o paradigma historicista, já desde meados do século XIX, tenha rapidamente alcançado popularidade entre os historiadores profissionais. Se uma perspectiva mais próxima do paradigma positivista - a busca da informação pura - parece ter atraído um número significativo de filósofos que escreveram história, bem como de outros eruditos ligados às formações sociais nascentes, já o paradigma historicista alcançou maior projeção entre os historiadores profissionais, mais habituados à percepção de que tudo o que se escreve parece estar ligado a uma posição particular que precisa ser decifrada no seio de sua especificidade e de sua complexidade.

Uma rápida visão panorâmica pode nos dar conta de como a concepção historicista da história, principalmente em função deste eficiente método de crítica documental que os historiadores da Escola Alemã estabeleceram, difundiu-se rapidamente por outros países. Em geral, os historicistas dos primeiros dois terços do século XIX, também fora da Alemanha, assumiram posições particularmente conservadoras que visavam legitimar os estados-nacionais. $\mathrm{Na}$ Inglaterra, por exemplo, teremos a obra de Thomas Babbington Macaulay (1800-1859), que pretende reconstituir o passado histórico com vistas a mostrar uma progressiva ascensão "em direção às formas da liberdade constitucional inglesa" (FONTANA, 2004, p.233), o que implica, para o caso do historiador whig Macaulay, em redesenhar a História da Inglaterra (1949) em termos de graduais vitórias dos reformistas whigs contra os tories, que aparecem como defensores do status quo e como freios à progressiva evolução política liderada pelos whigs ${ }^{32}$. Posteriormente, o historicismo alemão ganharia ainda mais força na Inglaterra, sobretudo a partir da divulgação de seu método por lorde Acton (1834-1902). Mas já reaparece aqui uma perspectiva de imparcialidade do historiador que faz lembrar os positivistas de sempre ou os historicistas dos primeiros anos do século XIX. Enquanto isto, no outro lado do Atlântico, o historiador norte-americano Frederick Jakson Turner (1861-1932) reforçava enfaticamente a natureza relativista da história em um texto de 1891 que discorria sobre "O Significado da História", antecipando o dito de Benedetto Croce de que "toda história é contemporânea" ao reafirmar que cada época reescreve necessariamente a história mais uma vez. A querela entre

\footnotetext{
32 O Whig Party, na Grã-Bretanha, era o partido que reunia as tendências liberais, contrapondo-se ao Tory Party, que constituía uma linha conservadora. Sobre os historiadores whigs, ver Burrow (1981). Sobre a historiografia britânica do século XIX, de modo geral ver Parker (1990).
} 
imparcialidade e relativismo do próprio sujeito produtor de conhecimento, deste modo, reeditava-se.

À parte os retornos e recuos ocasionais nesta complexa história da tomada de consciência histórica, o conservadorismo historicista dos primeiros tempos não impediu que deste paradigma surgissem novos caminhos historiográficos. O relativismo historiográfico é certamente a sua principal contribuição. Se nos detivermos nas implicações que já estavam presentes desde o primeiro princípio historicista - o da historicidade e relativismo de todas as sociedades humanas e objetos históricos - não é difícil perceber que seria só uma questão de tempo para que um dia viesse a ser atingida pelo Historicismo a aceitação do 'relativismo e historicidade do próprio historiador'. Afinal, se o objeto histórico é relativo, também o próprio historiador - ele mesmo passível de se tornar objeto histórico em um futuro distante - não pode ser mais do que igualmente relativo, imerso na historicidade, inevitavelmente ligado a pontos de vista particulares e à sua subjetividade intrínseca.

A consciência da historicidade era, por assim dizer, inevitável, e não poderia deixar de ser aperfeiçoada pelo arco historicista cada vez mais, à medida que o Historicismo se firmasse no decurso do século XIX. Foi assim que o setor mais relativista do Historicismo conseguiu adquirir especial vigor a partir da obra de pensadores como o historiador Gustav Droysen (1808-1884) e o filósofo Whilhelm Dilthey (1833-1911). Enquanto Ranke não era muito atormentado por dúvidas em relação à objetividade histórica nos primórdios do desenvolvimento do Historicismo (IGGERS, 1968, p.80), já Gustav Droysen, este historicista alemão que escreve na segunda metade do século XIX, passa a sustentar mais ou menos claramente a relatividade e a historicidade do próprio historiador, tal como fica explícito em um texto de 1881 intitulado "A objetividade do Eunuco", este pequeno ensaio que traz como título uma expressão bastante reveladora ${ }^{33}$ :

Eu considero este modo [o fato de se conceber como primorosa uma escrita da história sem qualquer perspectival como de uma parcialidade eunuca; e se a imparcialidade e a verdade históricas consistem nesse modo de observar as coisas, então os melhores historiadores são os piores, e os piores, os melhores. Eu não aspiro senão, nem mais nem menos, a deixar à mostra a verdade relativa ao meu ponto de vista. Quero mostrar como minha pátria, minhas

\footnotetext{
${ }^{33}$ A imagem relacionando "eunuco" e "objetividade" irá aparecer também com Friedrich Nietzsche, no célebre texto "Sobre a utilidade e os inconvenientes da história para a vida", publicado em 1874 como a $2^{a}$ Consideração Intempestiva: "Ou antes seria necessária uma raça de eunucos para guardar o grande harém da história universal? E nisso, a mais pura objetividade lhe calha muito bem. Quase parece que a sua tarefa consiste em fiscalizar a história a fim de que dela não se extraia nada, exceto histórias, mas nunca acontecimentos" (NIETZSCHE, 2005, p.110). Mais adiante, no mesmo ensaio, Nietzsche prossegue: "Mas, como já disse, esta é uma raça de eunucos e, para um eunuco, uma mulher vale tanto quanto outra, é sempre uma mulher, a mulher em si, eternamente inacessível - pouco importa, por conseguinte, o que fazeis, contanto que a própria história seja preservada na sua bela 'objetividade', vigiada por aqueles que não poderão jamais, eles próprios, faze história. [...] Eles próprios não são homens nem mulheres, nem mesmo entidades coletivas, mas somente seres neutros, ou melhor, para me expressar de maneira erudita, os Eternos objetivos" (NIETZSCHE, 2005, p.114).
} 
conviç̧ões políticas e religiosas, meu estudo sistemático me permitiram chegar a este ponto de vista. É preciso que o historiador tenha a coragem de reconhecer estas limitações, e se consolar com o fato de que o limitado e o particular são mais ricos que o comum e o geral. Com isso, a imparcialidade objetiva, a atitude não-tendenciosa do tão louvado ponto de vista de fora e acima das coisas, tal como recomenda Wachsmuth em sua teoria da história, é para mim desumana. Humano, para mim, é ser parcial" (DROYSEN, Historik, 1858; edição: 1977, p. 235-236).

Posições análogas à de Johan Gustav Droysen, assumindo impossibilidade de uma neutralização do historiador, também já haviam sido sustentadas, mesmo antes, por Gervinus (1805-1871) e Sybel (1817-1895), entre outros historiadores ligados ao historicismo alemão (RÜSEN, 1996, p. 85). Gervinus discutira a questão em um ensaio intitulado As Grandes linhas da História (1837), e Sybel em um texto intitulado Sobre o Estado da Moderna Historiografia Alemã (1856) ${ }^{34}$. Se Droysen e outros historicistas já começavam a reconhecer bem francamente a historicidade do próprio historiador, e a necessidade de levar isto em consideração naquilo que concerne à operação historiográfica, deve ser atribuída a Wilhelm Dilthey (1833-1911) a mais sofisticada defesa da necessidade de delinear uma postura metodológica específica para a História e para as demais ciências do espírito, por oposição ao padrão das ciências da natureza. Por outro lado, antes mesmo de Dilthey, Droysen já havia estabelecido em Historik (1858) a necessidade de clarificar a especificidade metodológica da História e outras ciências humanas. Para ele, haveriam três métodos científicos dotados de suas próprias especificidades: o especulativo (da filosofia), o físico (das ciências exatas e naturais), e o 'método histórico'. A estes três tipos fundamentais de métodos corresponderiam três gestos teórico-metodológicos específicos, que seriam respectivamente os gestos de "reconhecer", "explicar" e "compreender".

Wilhelm Dilthey (1833-1911) aprofundará o esforço de delinear a especificidade metodológica das ciências históricas ${ }^{35}$. Para ele, a discussão poderia ser dicotomizada nos termos de uma oposição entre as 'ciências do espírito' (Geisteswissenschaften) e as 'ciências da natureza' (Naturwissenschaften), considerando que esta oposição estaria relacionada ao contraste fundamental entre duas posturas metodológicas: a "compreensão" e a "explicação", respectivamente relacionáveis às ciências do espírito e às ciências da natureza ${ }^{36}$. Enquanto estas últimas poderiam se ater a uma "explicação exterior" dos fatos, já a História - ou qualquer outra

\footnotetext{
${ }^{34}$ A posição de Gervinus, um historiador mais próximo à primeira geração de historicistas, é mais um tanto mais ambígua. De um lado ele reconhecia um apartidarismo como "metodologicamente desejável". Mas, no mesmo trecho em que afirmava isto, também já predicava que o historiador deveria ser "um homem do partido do destino, um defensor natural do progresso, pois não se pode renunciar à defesa dos ideais de liberdade" (GERVINUS, 1837, p.92). Quando afirmava isto, nada mais estava fazendo senão assumir seu ponto de vista liberal.

${ }^{35}$ Para um estudo da Hermenêutica em Dilthey, ver Amaral (1994); Reis (2003), e também Testa (2004).

${ }^{36}$ Ao considerar o contraste entre os gestos de "explicar" e "compreender", Dilthey retoma as categorias que já haviam sido propostas por Droysen, mas desconsiderando o gesto de "reconhecer", que segundo Droysen (2009, p. 41) estaria relacionado ao 'método especulativo' da filosofia e da teologia.
} 
das hoje chamadas ciências humanas - estaria vinculada à necessidade de "compreender" (Verstehen) os fenômenos humanos, de entendê-los não apenas em sua forma externa, mas também por dentro, perscrutando seus sentidos, suas implicações simbólicas, ideológicas, vivenciais, ou, em uma palavra, seus significados ${ }^{37}$. Esta oposição entre a "compreensão" típica das ciências humanas, e a "explicação" típica das ciências naturais, tornar-se-ia clássica, uma referência não apenas para o historicismo como, de modo geral, para boa parte da historiografia do século XX em diante ${ }^{38}$. A partir daí, iremos encontrar em autores diversos, e também fora dos quadros do historicismo, a idéia de uma separação mais clara entre as "ciências da natureza" e as "ciências da sociedade" ${ }^{39}$. Outro nome importante nesta mesma direção será o de Georg Simmel (1858-1918), sociólogo historicista seguinte à geração de Wilhelm Dilthey ${ }^{40}$. A contribuição historicista, de todo modo, segue adiante pelo século XX, e para abordá-la adequadamente neste novo século, necessitaríamos de um artigo específico.

\section{Fontes Historiográficas}

ABBT, Thomas. Geschichte des menschlichen Geschlecht [História da Raça Humana]. Halle: 1776.

BEARD, Charles. That noble Dream. The American History Review. n. 41, p.74-87, 1935.

\footnotetext{
${ }^{37}$ É interessante observar que Dilthey avança efetivamente na direção de trazer uma maior especificidade metodológica às Ciências Humanas. Mas isto não significa que não possa ser discutido que, em algum nível, ele também não tenha se inspirado no modelo das ciências naturais. Este era um modelo muito forte para a época, e que tinha adquirido um fortalecimento adicional com o sucesso do evolucionismo de Darwin. Hans-Georg Gadamer, em certa passagem de Verdade e Método (1960), procura mostrar ainda as ligações entre Dilthey e a inspiração naturalista, apesar de seus avanços na distinção entre as duas posturas metodológicas: "Mesmo assim, Dilthey se deixou influenciar profundamente pelo modelo das ciências da natureza, embora quisesse justificar justamente a independência metodológica das ciências do espírito" (GADAMER, 2008, p.41). Ver, em seguida a estas palavras, a argumentação de Gadamer.

${ }^{38}$ Também Wilhelm Windelband (1848-1928), o principal neo-kantiano da Escola de Baden, explorou de maneira exemplar o projeto de sistematizar uma oposição entre as ciências nomotéticas (voltadas para a percepção de "nomos", isto é, "leis") e as ciências idiográficas, que trabalham com as singularidades geradas pelos fenômenos humanos e sociais. Em História e Ciência Natural (1894), Windelband discorre sobre o contraste entre o "método nomotético", que, tal como na Física e na Matemática, trataria de leis gerais, e o "método idiográfico", que, a exemplo da História e outras ciências humanas, se ocuparia dos fatos individuais. É significativa, aliás, a observação de Windelband de que não existe propriamente um contraste entre tipos de fatos relacionados a um padrão ou outro, mas sim uma oposição entre abordagens que se voltam para a percepção de leis gerais, e abordagens que se direcionam ao exame das singularidades ou das "formas particulares" (ou seja, os mesmos fatos podem ser tratados de uma perspectiva nomotética ou de uma perspectiva ideográfica, sendo isto o que diferenciaria as ciências de um tipo e outro).

${ }^{39}$ Pode-se indicar ainda o nome de Peter Winch (1972, p.32), e particularmente a obra Idéia de uma Ciência Social, para um esclarecimento particularmente claro sobre a separabilidade entre as "ciências da natureza" e as "ciências sociais", as primeiras relacionadas à abordagem da "Explicação", e as segundas relacionadas à abordagem da "Compreensão". Ainda com relação à separação entre os dois âmbitos de produção de conhecimento, mas já recusando a designação de "ciência" aos saberes que se relacionam aos estudos sobre o homem e sobre as sociedades humanas, ver o ensaio Mentes, cérebros e ciência, de Searle (1990, p.81). Para um panorama geral das posições a respeito, ver Hughes (1987, p.33-34).

${ }^{40}$ Simmel um criticará frontalmente o positivismo ao ressaltar que as "ciências históricas", por oposição às "ciências naturais", constituem uma atividade espiritual que coloca questões à realidade e lhe atribui uma significação (apud LÖWY, 1994, p.75). Reconhecendo concomitantemente a multiplicidade de pontos de vista e o fato, já apontado por Dilthey, de que cada um deles correspondia a uma visão parcial da realidade, a solução integradora de Simmel será do tipo sintético.
} 
BERNHEIM, Ernst. Introducción al estudio de la Historia. Barcelona: Labor, 1937 [original: 1889].

BOSSUET, Jacques Bénigne. Discurso sobre a História Universal [original: 1681].

BRAUDEL, Fernando. História e Ciências Sociais: a Longa Duração. Annales ESC, n. 4, 1958. p.725753 (republicado em Escritos sobre a História. São Paulo: Perspectiva, 1978. p.41-78) [original do artigo: 1958].

BÜSCH, J. G. Encyclopädie der historischen, philosophischen und mathematischen Wissenschaften [Enciclopédia das Ciências Históricas, Filosóficas e Matemáticas]. Hamburgo: 1775.

CHLADENIUS, Johann Martin. Allgemeine Geschichtswissenschaft [Ciência Histórica Universal]. Leipzig: Böhlau, 1752.

CHLADENIUS, Johann Martin. Einleitung zur richtigen Auslegung vernunftigerReden und Schiften. [Introdução para a correta interpretação de discursos e escritos racionais] Leipzig: 1741.

DILTHEY, Wilhelm. Introduction to the Human Sciences. Princeton: Princeton University Press, 1991. ( $1^{\circ}$ volume da Introdução ao estudo das Ciências do Espírito, 1883). Disponível em: <http://www.marxists.org/reference/subject/philosophy/works/ge/dilthey1.htm>. [original: 1883].

DROYSEN, J. Gustav. Historik: Vorlesungen über Enzyklopädie und Methodologie der Geschichte. (org. Peter Leyh). Stuttgart: Fromann-Holzboog, 1977 [português: Manual de Teoria da História. Petrópolis: Vozes, 2009. [original: 1868].

GADAMER, Hans-Georg. Verdade e Método. 9. ed. Petrópolis: Vozes, 2008. v.I e II [orig.: 1960].

GATTERER, J. C. Abhandlung vom Standort und Gesichtspunct des Geschichtsschreibers oder ter teutsche Livius [Ensaio sobre a localização geográfica e o ponto de vista do historiador]. Allgemeine historische Bibliothek. Halle, 1768, tit.V.

GERVINUS, Georg Gottfried. Grundzüg der Historik (As Grandes Linhas da História). Schriften zur Literatur. Berlim: Erler, 1962. p.49-103 [original: 1837].

GERVINUS, Georg Gottfried. Fundamentos de Teoria da História. Petrópolis: Vozes, 2010.

HALPHEN, Louis. Introduction à l'Histoire. Paris: PUF, 1946. HARTOG, F. Les Historiens Grecques. In: BURGUIÈRE, A (Org). Dictionnaire des Sciences Historiques. Paris: PUF, 1986.

HERDER, Johan Gottfried Von. Mais uma Filosofia da História [Também uma Filosofia da História para a Formação da Humanidade]. Lisboa: Antígona, 1995. [original: 1774].

HUMBOLDT, Wilhelm Von. Escritos de filosofia de la historia. Madrid: Tecnos, 1997.

HUME, David. Tratado da natureza humana: uma tentativa de introduzir o método experimental de raciocínio nos assuntos morais. São Paulo: UNESP, 2009. [original: 1739].

HUME, David. The History of England, from the Invasion of Julius Caesar to the Revolution in 1688. London: 1818. [original: 1754-1762]. 
KANT, Immanuel. Crítica da Razão Pura. São Paulo: Nova Cultural, 1987. [original: 1781].

MABILLON, Jean. De Re Diplomática. Paris: Charles Robustel, 1681-1709.

MEINECKE, Friedrich. El historicismo y su génesis. Mexico: FCE, 1982. [original: 1936].

MOMMSEN, Theodor. O ofício do historiador, (1874). In: MARTINS, Estevão de Rezende (org.). $A$ História Pensada. São Paulo: Contexto, 2010.

NIETZSCHE, Friedrich. Sobre a utilidade e desvantagens da História para a Vida, 1873 [incluído em Escritos sobre a História. São Paulo: Loyola, 2005]. [original: 1873].

PERTHES, Friedrich. Friedrich Perthes Leben. Gotha, 1872. [original: 1815].

RANKE, Leopold Von. History of the Latin and Teutonic Nations from 1494 to 1514. [História dos Povos Romanos e Teutônicos]. London: Kessinger Publishing, 2004. [original: 1824].

RANKE, Leopold Von. Pueblos y estados en la historia moderna. México: Fondo de Cultura Económica, 1979.

RANKE, Leopold Von. Die römischen Päpste in den letzten vier Jahrhunderten [História dos Papas, nos quatro últimos séculos]. London: Colonial Press, 1901. [original: Berlim: 1836].

RANKE, Leopold Von. Friedrich der Große [Frederico o Grande]. Leipzig, 1878.

RICKERT, Heinrich. Ciencia cultural y ciencia natural. Madrid: Calpe, 1922. [original: 1899]

SCHLÖZER, A. L. Von. Vorrede zu Abbé Mably, Von der Art, die Geschichte zu schreiben. [Prefácio ao abade Mably, a propósito da escrita da história] Estrasburgo: Dalzmann, 1784.

SEMLER, Hohann Salomo. Versuch einer freiern theologischen Lehrart [Tentativa de um método mais liberal para o ensino teológico]. Halle: C. H. Hemmerde, 1777.

SIMMEL, G. Die probleme der Gechichtsphilosophie. Eine erkentnistheoretische Studie. Munich: Verlag von Dunker und Humboldt, 1920.

SYBEL, Heinrich von. Über den Stand der neueren deutschen Geschichtsschreibung (Sobre o Estado da Moderna Historiografia Alemã, 1856). In: Kleine historische Schriften. Munich, 1863.

TROELTSCH, Ernst. Der Historismus und seine Probeme. Tubingen: J.C.B. Mohr, 1922.

VICO. Giambattista. Scienza Nuova. Opere. Milão: 1953. p. 365-905. [Ciência Nova. Rio de Janeiro: Record, 1999] [original: 1725].

WINDELBAND. História e Ciência Natural. [Geschichte und Naturwissenschaft, Freiburg, 1894. 


\section{Referências}

AMARAL, Maria N. de Camargo P. Período Clássico da Hermenêutica Filosófica. São Paulo: EDUSP, 1994.

ARÓSTEGUI, Julio. A Pesquisa Histórica: teoria e método. Bauru: EDUSC, 2006. [original: 1995].

BELLOTTO, H. L. Como fazer análise diplomática e análise tipológica de documento de arquivo. São Paulo: Arquivo do Estado/ Imprensa Oficial do Estado, 2002.

BENTIVOGLIO, Julio. Leopold Von Ranke. In: MALERBA, Jurandir (Org.). Lições de História. Rio de Janeiro: Porto Alegre, EdPuc, 2010b.

BENTIVOGLIO, Julio. Cultura Política e Historiografia Alemã no século XIX: A Escola Histórica Prussiana e a Historische Zeitschr. Revista de Teoria da História, Goiás, Ano 1, n.3, p.67-79, jun. 2010.

BENTIVOGLIO, Julio. História e Hermenêutica: a compreensão como um fundamento do método histórico - percursos em Droysen, Dilthey, Langlois e Seignobos. Opsis, v.7, n. 9, p.47-66, jul-dez. 2007.

BLANKE, Horst Walter. Historismus als Wissenschaftsparadigma. Einheit und Mannigfaltigkeit. In: FOHRMANN, Jürgen; VOSSKAMP, Wilhelm (Org.). Wissenschaft und Nation. München: Fink 1991. p.217-231.

BLANKE, Horst Walter e RÜSEN, Jörn (Org.). Von der Aufklärung zum Historismus. Strukturwandel des historischen Denkens. Wien: Schöningh, 1984.

BLANKE, Horst Walter (Org). Transformation des Historismus. Wissenschaftsorganisation und Bildungspolitik vor dem Ersten Weltkrieg. Interpretationen und Dokumente. Waltrop: Spenner 1994.

CALDAS, Pedro Spínola Pereira. Que significa pensar historicamente: uma interpretação da teoria da história de Johann Gustav Droysen. Rio de Janeiro: PUC, 2004.

CALDAS, Pedro Spínola Pereira. As dimensões do Historicismo: um estudo dos casos alemães. Opsis, v.7, n. 9, p.47-66, jul./dez. 2007.

DOCKHORN, Klaus: Der deutsche Historismus in England. Ein Beitrag zur englischen Geistesgeschichte des 19. Jahrhunderts. Göttingen: Vandenhoeck \& Ruprecht, 1950.

FALCON, Francisco J. Calazans. Historicismo: a atualidade de uma questão aparentemente inatual. Tempo. Rio de Janeiro, v. 4, p. 5-26, 1997.

FONTANA, Josep. A História dos Homens. Bauru: EDUSC, 2004. [original: 2000].

GOOOCH, G. P. History and historians in the nineteenth century. Boston: Beacon Press, 1968.

GRONDIN, J. Introdução à hermenêutica filosófica. São Leopoldo: Unisinos, 1991.

HAMILTON, Paul: Historicism. London: Routledge 1996. 
HARDTWIG, Wolfgang. Die Verwissenschaftlichung der Geschichtsschreibung zwischen Aufklärung und Historismus. In: KOSELLECK, LUTZ; RÜSEN (Org.). Formen der Geschichtsschrcibung. München, 1982. p.147-181.

HUGHES, J. La filosofia de la investigación social. México: Fondo de Cultura Económica, 1987.

IGGERS, Georg G. The German Conception of history. Middletown: Wesleyan University Press, 1968.

IGGERS, Georg. Historicism: The History and Meaning of the Term, Journal of the History of Ideas, v. 56, n.1, p. 129-152, jan. 1995.

JAEGER, Friedrich e RÜSEN, Jörn. Geschichte des Historismus: eine Einführung. Munich: Beck, 1992.

JAMESON, Fredric. Marxism and Historicism. New Literary History - a Journal of Theory and Interpretation, v. 11, p.41-73, 1979.

KOSELLECK, Reinhart. Futuro Passado: contribuição à semântica dos tempos históricos. Rio de Janeiro: Contraponto, 2006. [original: 1979].

LOWY, Michael. As Aventuras de Karl Marx contra o Barão de Muncchäusen. São Paulo: Cortez, 1994.

MARQUES, Juliana Bastos. O Conceito de Temporalidade e sua aplicação na historiografia antiga. Revista de História - USP, n. 58, p.44-66, 1. sem., 2008.

MARTINS, Estevão de Rezende (Org.). A História Pensada. São Paulo: Contexto, 2010.

MARTINS, Estevão de Rezende. Historicismo: o útil e o desagradável. In: VARELLA, Flávia et al. $A$ Dinâmica do Historicismo. Belo Horizonte: Argumentum, 2008.

MATA, Sérgio da. Leopold von Ranke (1795-1886). In: MARTINS, Estevão de Rezende (Org.). $A$ História Pensada. São Paulo: Contexto, 2010.

MOMMSEN, Wolfgang J. Le transformazioni dell'idea di nazione nella scienza storica tedesca del XIX e XX secolo. In: GERLONI, B. De (Org.). Problemi e metodi dellastoriografia tedesca. Torino: Einaudi, 1996.

MUHLACK, Ulrich. Geschichtswissenschaft im Humanismus und in der Aufklärung: die Vorgeschichte des Historismus. München: Beck, 1991.

LE GOFF, Jacques. "Documento / Monumento". In: ROMANO, Ruggiero (Org.). Enciclopédia Einaudi: História e Memória. Porto: Imprensa Nacional, 1984. p.95-106.

LE GOFF, Jacques. História e Memória. Campinas: Unicamp, 1990.

OEXLE, Otto Gerhard. Historismus. Überlegungen zur Geschichte des Phänomens und des Begriffs. In: Braunschweigsche Wissenschaftliche Gesellschaft. Jahrbuch 1986. p.119-155.

REILL, Peter Hans. The German Enlightenment and the Rise of Historicism. Los. Angeles: University of California Press, 1975.

PARKER, Christopher. The English historical tradition since 1850. Edinburgh: John Donald, 1990. 
REIS, José Carlos. Whilhelm Dilthey e a autonomia das ciências histórico-sociais. Londrina: EdUEL, 2003.

RUSEN, Jörn. Narratividade e Objetividade. Textos de História. Brasília, v.4, n.1, p.75-102, 1996.

SCHOLTZ, Gunter. Historismus/Historizismus. In: RITTER, Joachim; GRÜNDER, Karlfried. Historisches Wörterbuch der Philosophie Bd. 3. Basel: Schwabe, 1974. p.1137-1147.

SCHULZ, Walter. Philosophie in der veränderten Weltt. Stuttgart: Klett-Cotta, 1977.

SEARLE, J. Mentes, cerebros y ciencia. Madrid: Cátedra, 1990.

SOUTHARD, Robert. The Prussian School of History. Lexington: University Press of Kentucky, 1995.

TESTA, Edmárcio. Hermenêutica Filosófica e História. Passo Fundo: EdiUPF, 2004.

VARELLA, Flávia (Org.). A Dinâmica do Historicismo: revisitando a historiografia moderna.Belo Horizonte: Argvmentvm, 2008.

WINCH, Peter. La Idea de uma ciência social. Buenos Aires: Amorrortu, 1972.

WITTKAU, Annette. Historismus: Zur Geschichte des Begriffs und des Problems. Göttingen: Vandenhoeck \& Ruprecht, 1992.

Recebido em 13/09/2011

Aprovado em 14/12/2011 